\title{
A CHILD IN NEED OF CARE GUILLAIN BARRÉ SYNDROME
}

\section{Acres}

\section{OPSOMMING}

Guillian Barré-sindroom is die mees algemene polineuritis. Motoriese funksies word tot 'n groter mate as sensoriese funksies aangetal en die diagnose berus gewoonlik op simmetriese, distale en perifere spierswakheid. Sterftes aan die sindroom is gewoonlik die gevolg van respiratoriese arres en dus is vroeë diagnose en respiratoriese ondersteuning noodsaaklik.

Terapeutiese sowel as verpleegsorg berus veral op goeie waarneming van die omvang van verlamming en die voorkoming van komplikasies. In die verpleging van 'n kind met die sindroom is die erkenning en hantering van die kind se vrese weens die verlies van liggaamsfunksies belangrik. Derhalwe is die daarstelling van goeie kommunikasie ' $n$ noodsaaklike element van sorg.

It was a busy Friday afternoon when Anne was admitted to the paediatric intensive care unit. Anne was four years old with mousy coloured hair, long eyelashes and very expressive brown eyes. She was admitted with muscular weakness and her diagnosis was possible Guillain Barré Syndrome.

\section{GUILLAIN BARRÉ SYNDROME}

\section{(Infectious Polyneuritis)}

Infectious polyneuritis, also known as infectious neuronitis and Landry's or Guillain Barré syndrome, is probably the most common form of polyneuritis. It is an acute polyneuropathy in which motor dysfunction predominates over sensory disturbances. It is characterised by symmetrical ascending paralysis, including bilateral facial paresis or paralysis, and occasionally weakness of the bulbar and respiratory musculature.

\section{Incidence}

Statistical data relating to the incidence of Guillain Barré Syndrome in South African is unobtainable. However, American Literature inMiss L Acres, RN, RM, Registered Paediatric Nurse, DNE(Wits), DNA(Wits). Senior tutor, College for Advanced Midwifery and Paediatrics, Baragwaneth College of Nursing.

This article shared second place in the 1984 Johnson and Johnson - Curationis writing competition on "Nursing the child" in the category for registered nurses. dicates that all ages, all races and both sexes are affected. Although children are less often affected than adults, the incidence in the paediatric age group appears to be increasing, with higher susceptibility in children between the ages of four and ten years (Whaley, L.F.; Wong, D.L. 1983: p 1492-1493).

The average incidence of the syndrome is 1.7 per 100,000 population in America and geographic location, season and climate may affect the incidence of Guillain Barré Syndrome (Nelson, D et Al $1979: \mathrm{p}$ 1029-1033).

\section{Etiology}

The precise etiologic agent is unknown. The syndrome has recently been considered to be an immune reaction in which the primary target is the peripheral nervous system. The immune process may be triggered by exposure to an exogenous agent, recent infection or vaccination.

An antigen-antibody reaction occurs, causing lymphocytes to become sensitised to the peripheral nerve antigen and to attack the myelin of peripheral nerve tissue
(Smith, J.B. 1983 : p 283).

Precipitating factors include: Ebstein Barr virus; measles, mumps, influenza, enteric viruses, mumps/ rubella vaccination, diptheria, pertussis, tetanus vaccination, (Shelov, S.P. et al 1984).

\section{Pathophysiology}

The pathological changes that take place are primarily of segmental demyelination of the peripheral nerves, that is loss of the fatty myelin sheath (see figure 1).

Although the myelin is affected, the structure of the axon is usually spared, these degenerative changes affect spinal and cranial nerve roots in ascending order. The result of these degenerative changes is the slowing or total blockage of nerve conduction, producing a rapidly ascending partial or complete paralysis of muscles innervated by the nerves involved.

Concomitant changes are oedema, inflammation and compression of nerve roots within the dural sheath. The anterior spinal roots or motor neurones are primarily affected, causing disturbance in movement. Posterior spinal roots or

\section{Figure 1: Segmental demyelination of the peripheral nerves}

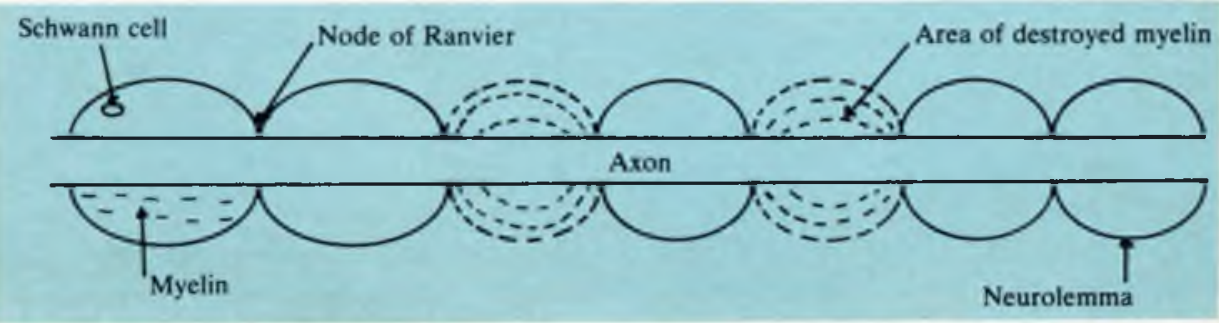


sensory neurones are also affected resulting in disturbances of sensation. Other nerves involved are the cranial and autonomic nerves.

\section{Clinical presentation}

Paralysis is usually preceded by a mild influenza-like illness or sore throat.

The primary presenting feature of Guillain Barré syndrome is symmetrical, distal, peripheral muscle weakness. Leg weakness is pronounced but arm weakness may also be present and may progress to full flaccid paralysis with loss of 'reflexes.

Facial, extraocular, lingual, pharyngeal and laryngeal muscles may be affected. Evidence of intercostal and phrenic nerve involvement includes breathlessness with shallow irregular respirations. Most patients complain of muscle tenderness, cramps or sensitivity to slight pressure. Urinary incontinence or retention and constipation are frequently present

The height of paralysis is usually reached within a few days after onset, although the progression of the paralysis may persist for up to three weeks.

Sensory involvement is variable Position sense as well as sense of touch, pain and temperature may be impaired. Paraesthesia numbness or tingling) of toes is present in a glove-and-stocking fashion, tending to be intermittent during the initial stage of the illness.

Cranial nerve involvement is present to some degree in the majority of patients. The facial nerve is most commonly affected. Dysphagia and laryngeal paralysis implicate the glossopharyngeal nerve.

Autonomic dysfunction manifests itself mainly by orthostatic hypotension and/or transient hypertension. Excessive sympathetic activity is evidenced by hypertension, persistent sinus tachycardia, episodes of delirious behaviour, sudden profuse sweating and peripheral vasoconstriction. Insufficient sympathetic activity results in orthostatic hypo- tension and poor tone, causing pooling in dependent areas. Excessive parasympathetic activity results in bradycardia, facial flushing and generalised extreme warmth. Insufficient parasympathetic activity results in sphincter disturbances (Lichtenfeld, P 1971 : p 771-780).

\section{Prognosis of Guillain Barré syndrome}

Guillain Barré Syndrome occurs in various degrees of severity, but all affected patients will require hospitalisation. Some children may never progress to full paralysis and may only require observation, whereas others will require acute care. The general health of the child and the extent of the paralysis will influence the outcome of the illness.

Almost all deaths result from respiratory failure, therefore early diagnosis and respiratory support are essential. Muscle function may begin to return any time between two days and two weeks after onset of the disease, recovery being dependent on the extent of demyelination. The longest peripheral nerves are the last to recover and the greater the degree of paralysis the longer the recovery phase, which may extend from a few weeks to months.

\section{Diagnostic evaluation}

Currently, there is no specific test to confirm the diagnosis of Guillain Barré syndrome. The diagnosis is based on the collective information gained from the patient's history, clinical symptomatology, progression and laboratory results. Cerebrospinal fluid analysis reveals an increased protein concentration but in essence other laboratory studies are non-contributory.

\section{Therapeutic management}

The management of Guillain Barré syndrome is symptomatic and depends upon the stage of illness and the extent of muscular involvement. The management regime is one of highly supportive care

Corticosteriod therapy has been used without conclusive results. Plasmapheresis has been investigated, based on the idea that the etiology is immunologic - by removal of the circulating antibody specific for peripheral nerves, clinical improvement should follow (Smith, J.B. 1983: p286)

\section{Nursing Care}

The therapeutic care of this child is highly supportive and so is the nursing care. The emphasis of care is on close observation to assess the extent of the paralysis and on prevention of complications.

During the acute phase of the disease the child's condition should be carefully observed for possible difficulty in swallowing and respiratory involvement. There should be a respirator attached to the patient with a cardiac monitor on standby. Suction apparatus is essential, with a tracheostomy tray and vasoconstrictor drugs available at the bedside. Vital signs and level of consciousness are monitored halfhourly.

For the child who develops respiratory dysfunction, the care is the same as that for any child with respiratory distress requiring mechanical ventilation.

Throughout the recovery phase special emphasis is placed on prevention of complication - including good postural alignment, frequent change of position and passive exercises. Children with oral and pharyngeal involvement are usually fed by means of a nasogastric tube to ensure adequate feeding.

Bowel and bladder care are needed to avoid constipation and retention of urine. Sensory impairment makes the child susceptible to trophic ulcers therefore skin care and care to pressure areas is important to prevent a pressure sore.

Physiotherapy is limited to a passive range of movements during the acute stage of the illness. Later, as the disease stabilises and recovery 
begins, an active physiotherapy programme is implemented to prevent contracture deformities and to facilitate recovery of muscles. This will include active exercise, gait training and perhaps the use of callipers.

\section{Communication}

Recognition of the child's fears and feelings of loss of body control is a primary element in providing care during the acute phase of the syndrome. In some instances, children may find themselves totally paralysed, intubated and helpless within 24 hours after admission to the paediatric intensive care unit.

Initially the parents will also be fearful and helpless. It is of the utmost importance that communication be established. The child and family need to feel a sense of security in the intensive care environment.

If the child still has facial muscle control it is possible for him to communicate by means of eye signals and head nodding. The use of picture boards and language charts is helpful. At the bedside, the nurse should always speak to the child. tell the child what will happen, talk about topics familiar to the child and report news from home. The parents can become involved by reading stories and assisting in the child's daily care.

Establishing a daily routine is helpful in allowing the child to gain some control over the environment and assisting the child to become familiar with the hospital personnel.

The recovery period of Guillain Barré syndrome may be as long as several months, therefore open communication and the establishment of trust are extremely important.

\section{Resumé}

Anne was an only child who lived with her parents on a farm not far from the city. She loved the animals and would spend as much time as possible with her father helping him with certain activities on the farm. Even though she was only four years old, her father described her as his little helper.

Anne had not really been ill before, apart from the occasional cold. The course of her illness, Guillain Barré syndrome, had followed very much the same pattern as that described in the text books. She experienced a cold and sore throat about a week before the onset of symptoms of muscle weakness. The progress of the disease had been rather rapid and within 36 hours of admission she had been intubated and was receiving mechanical ventilation.

It is customary in most intensive care units, particularly in the paediatric units, to have a child cared for throughout his/her stay by the same team of people as far as possible. Hospitalisation is frightening enough for the child, let alone admission to an intensive care unit.

I was on duty at the time of Anne's admission and she became my patient/responsibility/friend. Anne was the first child with Guillain Barré syndrome that I had nursed. I became extremely interested in her care, which had to be highly supportive.

One thing worried us and that was our inability to communicate adequately with Anne (remember she had been intubated and was on a ventilator). We were continuously met with fearful brown eyes. We tried pictures, stories, and animal noises - but nothing seemed to help. Not even her parents seemed to manage and they tried so hard. We were all beginning to despair and then Charlie the clown came into her life.

As I walked past a toy shop one day I was wondering if there was anything that could possibly help us to communicate with Anne. I stopped to look into the window and there was Charlie, a hand puppet, almost jumping up and asking to be bought. There wasn't a second thought and the next morning Charlie and I went on duty together.

My first inclination was to introduce Charlie straight away. However, I decided to wait for a quieter moment. There was a certain amount of apprehension on my part as I feared Charlie's rejection. The big moment arrived and for the first time since intubation we saw those big brown eyes smile.

Charlie was to play an important role in Anne's care - he was always available to help us with medical and nursing procedures and the games he played made physioand occupational therapy fun. His help was invaluable and above all, he helped to foster two-way communication.

Anne was intubated for two weeks after which she was weaned from the ventilator. She continued along a slow but steady path to recovery. She spent another three weeks in the intensive care unit and was then transferred to an outlying ward. Here, with Charlie's help, she went from strength to strength until discharge two months later.

Residual damage was a persistent paralysis of one of her toes. Charlie and Anne had become inseparable and $I$ am told that this situation remained so for many years.

\section{Conclusion}

The facts which have been related emphasise the importance of communication in the care of our patients, a subject about which much has been written. We cannot manage our lives without communication.

As nurses each of us has special patients whom we remember long after discharge. Anne and Charlie are special as they have contributed to both my professional and personal growth.

\section{REFERENCES}

1. Keally, S. (1971) Respiratory care in Guillain Barré syndrome. American joumal of nursing 77:58-60

2. Lichtenfeld, P. (1971) Automatic dysfunction in Guillain Barré syndrome. American journal of medicine. 50: 772 780 .

3. Meakin, A. (1971) The nerve impulse and disordered transmission related physiology part 1. Nursing mirror 145: 17-18.

4. Nelson, D et al (1979) Results of the national surveillance for Guillain Barré syndrome. Neurology. 29: 1029 1033.

5. Shelov, S.P. et al (1984) Primary care paediatrics - a symplomatic approach Connecticut. Appleton-centurycrofts. 1st Ed.

6. Smith, J.B. (1983) Paediatric critical care New York Wiley 1st Ed.

7. Whaley, W.F; Wong, D.L. (1983) Nursing care of infant and children St. Louis, C.V. Mosby 2nd Ed. 